\title{
POŠTA
}

TELEKOMUNIKÁCIE A

ELEKTRONICKYY OBCHOD

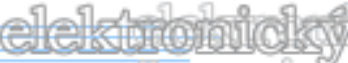

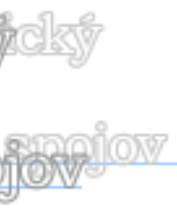

\section{ANALÝZA VYUŽÍIVANIA SLUŽIEB eGOVERNMENTU V SR}

\author{
Lucia Madleňáková ${ }^{1}$ - Radovan Madleňák ${ }^{2}$
}

\section{Úvod}

Informačná spoločnost' je spoločnost', ktorej prioritné aktivity sú zdiel'anie, tvorba a použivanie informácií. Úlohou informačnej spoločnosti je predovšetkým zjednodušit' a sprehl'adnit' získavanie a tvorenie informácií, čo následne povedie k zvyšovaniu životnej úrovne spoločnosti a takisto zlepšovaniu komunikácie vo všetkých oblastiach spoločnosti.

Informatizácia spoločnosti je pojem, ktorý sa stále viac a viac dostáva do popredia vo všetkých médiách. Ide o proces, ktorý popisuje zavádzanie používania informačnokomunikačných technológií do bežného života. Pod samotnou informatizáciou spoločnosti sa rozumie transformovanie „,analógového“ sveta na svet „digitálny“.

\section{Teoretické východiská}

V metodickom pokyne na použitie odborných výrazov pre oblast' informatizácie spoločnosti je informatizácia charakterizovaná ako cielavedomé a systémové zavádzanie informačných a komunikačných technológii do všetkých relevantných oblastí spoločenského, politického a hospodárskeho života s ciel’om zvýšit poznatkový potenciál spolocnosti.[1]

e-Government je súčast’ou celkového procesu informatizácie spoločnosti. Pomenovanie vychádza zo skratky slovného spojenia electronic government (elektronická vláda). V mnohých informačných zdrojoch sa však môžeme stretnút' aj s pojmami E-gov, Connected government, On-line government, Digital government.

e-Government predstavuje formu vzt'ahov vo verejnej správe, ktoré sú vykonávané pomocou informačno-komunikačných technológií a on-line komunikácie. Taktiež popisuje použitie technológií, ktoré by mali slúžit' na ul'ahčenie operácií verejnej správy a sprostredkovanie služieb a informácií podnikatel'om a občanom.

V publikácii United Nations Economic Survey je e-Government charakterizovaný nasledovne: ,E-Government je mocný nástroj pre vývoj l'udstva a nevyhnutný pre dosiahnutie medzinárodne schválených ciel'ov, vrátane rozvojových ciel'ov tisicročia ".[12]

Organizácia pre hospodársku spoluprácu a rozvoj vidí v e-Governmente viac ako len vládu s predponou „e“. Je to forma vlády, ktorá prináša lepšie politické výsledky, služby vysokej kvality, a väčšie zapojenie obyvatelstva.[2]

Okrem pojmu eGovernment $v$ súčasnej dobe sa $v$ tlači ale i odbornej literatúre objavuje pojem eGovernance. Indický vedec C.S.R. Prabhu charakterizuje e-Governance ako

\footnotetext{
${ }^{1}$ Ing. Lucia Madleňáková, PhD., Katedra spojov, FPEDAS, Žilinská univerzita v Žiline, tel.: +421415133125, email: Lucia.Madlenakova@fpedas.uniza.sk

${ }^{2}$ doc. Ing. Radovan Madleňák, PhD., Katedra spojov, FPEDAS, Žilinská univerzita v Žiline, tel.: +421415133124, e-mail: Radovan.Madlenak@fpedas.uniza.sk
} 
formu e-businessu vo vládnutí, obsahujúca procesy a štruktúry zahrnuté $v$ doručovaní elektronických služieb verejnosti.[8] Podl'a japonského vedca Toshia Obiho, e-Governance nie je nič viac a nič menej ako vládnutie v elektronickom prostredí. Vládnutie tomuto prostrediu a vládnutie v tomto prostredí, oboje si vyžadujú elektronické prístroje.[6]

eGovernment a eGovernance je však možné definovat' aj ako dva vel'mi odlišné pojmy. eGovernance je širšia téma, ktorá rieši širšie spektrum vzt’ahov a sietí vo vnútri vlády týkajúcich sa požívania a aplikovania informačno-komunikačných technológií. eGovernment je užšia disciplína, ktorá rieši rozvoj on-line služieb občanom. eGovernance je širší koncept, ktorý definuje a posudzuje dopady technológií na správu vlády a vzt’ahy medzi zamestnancami verejnej správy a širšou verejnost’ou. eGovernment je inštitucionálny prístup $\mathrm{k}$ právnym politickým operáciám. eGovernance je procedurálny prístup ku kooperácií administratívnych vzt’ahov.

Vo všeobecnosti možno pozitívne a negatívne aspekty eGovernmentu zhrnút' nasledovne:

\begin{tabular}{l|l} 
Výhody & Nevýhody \\
Rýchlost' procesov vo verejnej správe & Neosobnost' - absencia osobného kontaktu \\
Kvalitnejšie služby & Nedostatočná digitálna gramotnost' \\
Väčšia účast' občanov (vyjadrenie názorov) & Možnost' straty dát \\
Menšia spotreba papiera & Nekompatibilita s niektorými systémami \\
Menšie náklady na prevádzkovanie & Možnost' zachytenia dát neautorizovanými \\
Lepšia informovanost' obyvatel'stva & osobami \\
Nepretržitá dostupnost' & Náklady na vzdelávanie obyvatel'stva
\end{tabular}

Nové služby

Menšia nezamestnanost’

\section{Analýza súčasného stavu}

Implementácii eGovernmentu do praxe predchádza fáza dlhodobých príprav najmä z dôvodu zložitosti celého procesu, ktorý si vyžaduje nielen koncepčný, ale hlavne strategický prístup so zohl'adnením všetkých aspektov, ktoré existencia eGovernmentu ovplyvní. Strategické dokumenty tak predstavujú základ správneho budovania fungujúceho a užitočného eGovernmentu. [3]

Prioritným dokumentom, ktorý definuje strategické ciele procesu zavedenia eGovernmentu v SR a stanovuje kroky vedúce k modernizácií verejnej správy a elektronizácií jej služieb, je Stratégia informatizácie verejnej správy schválená uznesením vlády SR č. 131/2008 dňa 27. februára 2008. Na tento zásadný dokument nadväzuje Národná koncepcia informatizácie verejnej správy, ktorá stanovuje architektúru integrovaných informačných systémov verejnej správy a definuje štandardy ich budovania, pričom ciel'om je zabezpečit' interoperabilitu a nezávislost' na technologických platformách.

Okrem uvedených dokumentov bol v roku 2011 schválený materiál Revízia budovania eGovernmentu, ktorého úlohou je hodnotenie praktickej roviny implementácie projektov s dôrazom na potrebu revidovania koncepčných východísk.

Rovnako dôležitý strategický dokument v oblasti rozvoja IS predstavuje Koncepcia rozvoja IS verejnej správy. Tento dokument definuje najmä ciele, technické, organizačné a technologické nástroje i architektúru IS VS. [7]

V súčasnosti Slovenská republika patrí medzi krajiny EÚ s nízkym stupňom v oblasti inovatívnosti, t. j. dosahuje pomalý rast na to, aby bol dobehnutý priemer inovačnej výkonnosti krajín EÚ. Chýbajúci potenciál vedomostnej ekonomiky je tým pravým dôvodom, ktorý by zvýšil podiel inovačných aktivít v spoločnosti a pretransformoval by ich do zdrojov 
trvalého rastu, pretože základným pilierom vedomostnej ekonomiky je práve informačná spoločnost'.

$\mathrm{V}$ úrovni informatizácie spoločnosti patrí Slovensko, napriek miernemu pokroku v posledných rokoch, k najzaostávajúcejším krajinám EÚ, tzn. že zaostáva nielen za krajinami EÚ v prvej pätnástke, ale aj za väčšinou nových členských krajín.

\subsection{Príčiny zaostávania}

Príčiny súčasnej nízkej úrovne eGovernmentu je možné stanovit' ako na strane ponuky, tak aj na strane dopytu po e-službách, ktoré súvisia najmä s nízkou penetráciou internetu na území Slovenska, a taktiež so zručnost’ami používatel'ov IKT. Nedostatočná ponuka kvalitných elektronických služieb je kl'účovou príčinou nízkej penetrácie širokopásmového pripojenia a úrovne informačnej spoločnosti v SR. Na strane dopytu sa nachádza bariéra $v$ podobe nedostatočnej cenovej a fyzickej dostupnosti pripojenia v najzaostávajúcejších regiónoch Slovenska a nízka kúpyschopnost' populácie.

Vo všeobecnosti je príčinou zaostávania SR za priemerom v EÚ fakt, že: [10]

- v predchádzajúcom období nebola informatizácia reálnou prioritou vlády,

- neexistovala základná legislatíva, ktorá by umožnila koncepčne začat' budovat' eGovernment (zákon o ISVS bol schválený až v roku 2006 a predstavoval len začiatok v budovaní konzistentného právneho rámca, doteraz chýba viacero zákonov a vykonávacích predpisov o zrovnoprávnení papierovej a elektronickej formy komunikácie),

- IS VS bol rozvíjaný skôr evolučne ako revolučne a tým pádom takýto prístup prináša množstvo drahých IS, ktoré navzájom nekomunikujú a množstvo nekoordinovaných služieb VS, ktoré občanov zat’ažujú a sú pre nich finančne náročné. Chýba nielen komunikácia a zosúladenie medzi jednotlivými orgánmi ústrednej správy, ale aj koordinácia medzi štátnou správou a samosprávou.

Dôsledkom prístupu k doterajšej informatizácií VS je spomínaný fakt, že SR je v eGovernmente a elektronickom obchode zarad'ovaná na koniec rebríčka krajín EÚ. Chýbajú základné služby eGovernmentu a chýba ponuka užitočného digitálneho obsahu.

\section{2 Ústredný portál verejnej správy}

Ústredný portál verejnej správy (ÚPVS) je definovaný ako: ,informačný systém verejnej správy na poskytovanie služieb a informácií verejnosti prostredníctvom spoločného prístupového miesta v sieti internet podl'a zákona č.275/2006 Z. z. o informačných systémoch verejnej správy.“ [17] Portál eGovernmentu zabezpečuje centrálny a jednotný prístup $\mathrm{k}$ informačným zdrojom a službám verejnej správy. V súčasnosti sú mnohokrát súčastou informačných serverov jednotlivých rezortov informácie (rady, popisy, návody), ktoré návštevník hl'adá. Ciel'om ÚPVS je tieto informácie a služby zintegrovat' a prístupnou a prehl'adnou formou poskytovat' používatel'ovi. Medzi najvýznamnejšie úlohy portálu patrí: „,nasmerovanie použivatel'a na využitie konkrétnej elektronickej služby verejnej správy využitím relevantných informačných zdrojov."

A však štúdia eGovernment Benchmark 2010 potvrdila skúsenosti Slovákov, že ", napriek rastúcej dostupnosti elektronických služieb tieto nie sú naviazané na riešenie životných situácii občanov a podnikatel’ov a je potrebné opakovane predkladat žiadosti s rovnakými údajmi na rôznych miestach pre vybavenie jednej konkrétnej životnej situácie, napr. zakladanie spoločnosti alebo strata zamestnania. “[16]

Súčasná výzva je teda jasná - „je potrebné prepojit' balíky služieb tak, aby boli relevantné pre zákazníka, a aby boli také, aké zákazník vyžaduje, " tvrdí Graham Colclough, viceprezident pre globálny verejný sektor konzultačnej spoločnosti Capgemini. [16] 


\section{Ciele a metodika}

Informatizácia spoločnosti na Slovensku a meranie jej úrovne prebieha pod záštitou Ministerstva financií Slovenskej republiky. Od roku 2009 Ministerstvo financií SR pravidelne uskutočňuje Prieskum spokojnosti s eGovernmentom. Na základe publikovaných výsledkov je možné skonštatovat', že v roku 2011 neboli zaznamenané významné zmeny vo vývoji znalosti či využívania e-služieb VS v segmente občan. Približne 39\% populácie využilo aspoň jednu e-službu VS. Rozvinutost' sledovaných e-služieb VS viac-menej zodpovedá predstavám populácie, aj ked' oproti roku 2010 bol identifikovaný nárast nespokojnosti. Za najväčšie výhody e-služieb VS respondenti považujú úsporu času a finančných prostriedkov, jednoduchost' a pohodlie vybavovania cez internet, avšak stále pretrváva nedostatočná informovanost' a propagácia e-služieb. Najväčší potenciál elektronického riešenia úradných záležitostí bol zistený pri službách ako podanie dane z príjmu, vybavovanie osobných dokladov a podanie dane z nehnutel'nosti. Výhody využívania e-služieb VS ako úspora času, zjednodušenie procesov pri vybavovaní, ušetrenie cestovných nákladov, časová neobmedzenost' pri vybavovaní a iné, patria medzi najvýznamnejšie aktivátory popularizácie pre rozvoja eGovermentu na Slovensku. Jednou z foriem podpory záujmu občanov pre využívanie e-služieb je poskytnút' im kompletné a aktuálne informácie o možnostiach eGovermentu a to najlepšie na jednom mieste. $\mathrm{V}$ tejto oblasti prieskum odhalil značné rezervy, pretože len necelých $27 \%$ populácie pozná webové sídlo www.portal.gov.sk, ktoré by malo slúžit’ práve na tento účel. [18]

V segmente používatel'ov e-služieb VS (t. j. tých, ktorí za posledných 12 mesiacov riešili elektronicky sledované úradné záležitosti) Index spokojnosti s e-službami VS v roku 2011 klesol zo 61,4 bodov (max. počet bodov $=100$ ) na 55,6 bodov oproti predošlému sledovanému obdobiu. Dôvodom je predovšetkým dôsledok nárastu požiadaviek a očakávaní občanov, ktorí sú počítačovo zdatní, a ktorí elektronizáciu VS považujú v súčasnosti už za nevyhnutný znak modernej spoločnosti. Najviac využívané e-služby VS v tomto segmente sú: služby katastra nehnutel'ností, vyhl'adávanie pracovného miesta a ročné zúčtovanie zdravotného poistenia. Súčasní používatelia e-služieb VS deklarujú svoj záujem najmä o využitie možnosti hlasovania cez internet - e-voting, podanie dane z nehnutel'nosti, možnost' sledovania stavu dôchodkového účtu elektronicky. Znalost' ústredného portálu verejnej správy (www.portal.gov.sk) je $\mathrm{v}$ tomto segmente na úrovni 54\%, môžeme hovorit' o vel'kom potenciáli rozvoja znalosti tohto portálu. [18]

Využívanie internetu v biznis segmente je takmer na úrovni $100 \%$, s čím súvisí aj predpoklad vyššieho percenta využívania sledovaných e-služieb VS (až o $42 \%$ oproti rezidenčnému segmentu). $81 \%$ firiem uviedlo, že pri riešení aspoň jednej zo sledovaných úradných záležitostí využili internet. Znalost' ÚPVS, ako najdôležitejšieho zdroja informácií o elektronických službách, nie je na uspokojivej úrovni. Len 53\% firiem pozná ÚPVS a $87 \%$ z tých, čo ho poznajú ho aj využívajú. Skúsenosti firiem s využívaním e-služieb vedú k uspokojivým hodnotám indexu spokojnosti (67,7 bodov zo 100), pričom dôvodmi nespokojnosti je predovšetkým nekomplexnost' e-služby (nemožnost' vybavit' úradnú záležitost' plne elektronicky) a neinformovanost' o všetkých možnostiach elektronického riešenia služieb. [18]

V mesiacoch marec až máj 2012 bol v rámci spracovania okruhu tém bakalárskych prác riešených na Katedre spojov, zameraných na analýzu stavu implementácie a využívania služieb eGovernementu vSR realizovaný kvantitatívny marketingový výskum. V nasledujúcej časti príspevku budú prezentované čiastkové výsledky marketingového výskumu. Ide o Prieskum realizovaný formou elektronického dotazníka s ciel'om analyzovat' spokojnost' s využívaním služieb eGovernmentu v segmente občan. Atribúty a metodiku uskutočneného prieskumu charakterizuje nasledujúca tabul'ka: 
Tabul'ka 1 Základné charakteristiky prieskumu

\begin{tabular}{|c|c|}
\hline Typ prieskumu & kvantitatívny \\
\hline Vzorka & 90 respondentov \\
\hline \multirow[t]{4}{*}{ Štruktúra respondentov } & $\begin{array}{l}\text { Pohlavie } \\
\text { - Muži }-46 \% \\
\text { - Ženy }-54 \%\end{array}$ \\
\hline & $\begin{aligned} \text { Vek } & \\
\text { - } & 15-25 \text { rokov }-77 \% \\
\text { - } & 26-35 \text { rokov }-11 \% \\
\text { - } & 36-50 \text { rokov }-12 \%\end{aligned}$ \\
\hline & $\begin{array}{l}\text { Sociálny status } \\
\text { - Študent }-66 \% \\
\text { - Zamestnaný - } 29 \% \\
\text { - Materská/rodičovská dovolenka }-3 \% \\
\text { - Nezamestnaný }-2 \%\end{array}$ \\
\hline & $\begin{aligned} & \text { Kraj } \\
& \text { - Žilinský }-81 \% \\
& \text { - } \text { Banskobystrický - } 10 \% \\
& \text { - Trenčiansky }-4 \% \\
& \text { - Bratislavský }-3 \% \\
& \text { - Nitriansky }-1 \% \\
& \text { - Košický }-1 \%\end{aligned}$ \\
\hline Metóda zberu dát & $\begin{array}{l}\text { Elektronický dotazník vytvorený prostredníctvom nástroja } \\
\text { Google Docs s umiestnením na webovom sídle }\end{array}$ \\
\hline Štruktúra dotazníka & $\begin{array}{l}\text { - } 11 \text { základných otázok formulovaných pre potreby } \\
\text { splnenia výskumného ciel’a } \\
\text { - } 4 \text { identifikačné otázky pre potreby hlbšej analýzy } \\
\text { a skúmania dôsledkov }\end{array}$ \\
\hline Obdobie zberu dát & Marec - Máj 2012 \\
\hline Výskumné ciele & $\begin{array}{l}\text { - Zistit' preferovaný spôsob komunikácie s verejnou } \\
\text { správou } \\
\text { - Zistit' a analyzovat' úroveň povedomia } \\
\text { o eGovernmente v segmente občan } \\
\text { - Zistit' úroveň a účel a očakávania a využívania služieb } \\
\text { eGovernmentu } \\
\text { - Zistit' potreby segmentu občan vo vzt'ahu } \\
\text { k využívaniu elektronického podpisu } \\
\text { - Zistit' požiadavky a využívanost' webstranky } \\
\text { portal.gov.sk }\end{array}$ \\
\hline
\end{tabular}

\section{Výsledky a diskusia}

Analýza spracovania prieskumom získaných zdrojových údajov bola rozdelená do niekol'kých častí v nadväznosti na výskumné ciele. Využívanie internetu je záležitost', ktorá podmieňuje úspešnost' služieb ponúkaných prostredníctvom internetu. Prvá výskumná otázka bola zameraná na zist'ovanie účelu využívania internetu. $64 \%$ opýtaných respondentov internet používa na vzdelávanie, $89 \%$ využíva internet ako zdroj zábavy, $47 \%$ používatel'ov 
prostredníctvom internetu pracuje. 60\% dopytovaných označilo možnost' „nakupovanie“, $27 \%$ využíva internet na úradné záležitosti.

\section{Komunikácia s verejnou správou}

Pre výskum bolo určených 5 základných foriem komunikácie s verejnou správou. Osobný kontakt, telefonicky, prostredníctvom internetu, poštou, mobilným telefónom. Každý respondent mohol zvolit' len jednu možnost', ktorú najviac uprednostňuje. Výsledky ukázali že občania stále viac uprednostňujú osobný kontakt pred elektronickým. Vybavovanie úradných podaní osobným kontaktom uprednostnilo $61 \%$ z opýtaných. Internetový kontakt s verejnou správou uprednostňuje $27 \%$, používanie telefónu zvolilo $7 \%$ opýtaných. Spokojnost' s poštovou komunikáciou preukázalo 3\% opýtaných, mobilné telefóny získali slabé 2\%. Porovnaním týchto údajov s údajmi z roku 2007, ktoré boli publikované v Publikácií Občania online, kde podl'a Velšica a jeho výskumu sa komunikácia formou osobného kontaktu umiestnila rovnako na prvom mieste avšak so 68\%. Druhou najvyužívanejšou formou komunikácie bolo vybavovanie úradných záležitosti telefonicky (12\%), na tret'om mieste bolo využívanie internetu s $11 \%$ a poštový styk spolu s mobilným telefónom získali $6 \%$ a $2 \%$.

Z oboch konfrontovaných prieskumov je zrejmé, že percentuálny podiel osobnej návštevy úradu klesá a internetový styk si získava čoraz viac priazne. Môžeme to pripísat' osvete používania elektronických zariadení a čoraz väčšej dostupnosti internetu. Je možné predpokladat', že spôsobilými na elektronickú komunikáciu s verejnou správou sa stávajú čoraz viac l'udia, ktorí prišli do styku s informačno-komunikačnými technológiami od raného veku a táto forma komunikácie je pre nich prirodzená.

\section{Povedomie o pojme eGovernment}

Napriek tomu že história elektronizácie verejnej správy na Slovensku siaha až do roku 1999, nie všetci dokážu pozitívne odpovedat' na otázku „Zaregistrovali ste pojem eGovernment, a viete čo znamená?“. Zo všetkých opýtaných, $50 \%$ počulo a presne vedelo čo pojem eGovernment predstavuje. $22 \%$ pojem zaregistrovalo, avšak nie presne vedia čo znamená, $10 \%$ respondentov termín počulo, avšak nemajú vedomost' o tom, čo znamená. Ostatných 18\% o eGovernmente vôbec nepočuli.

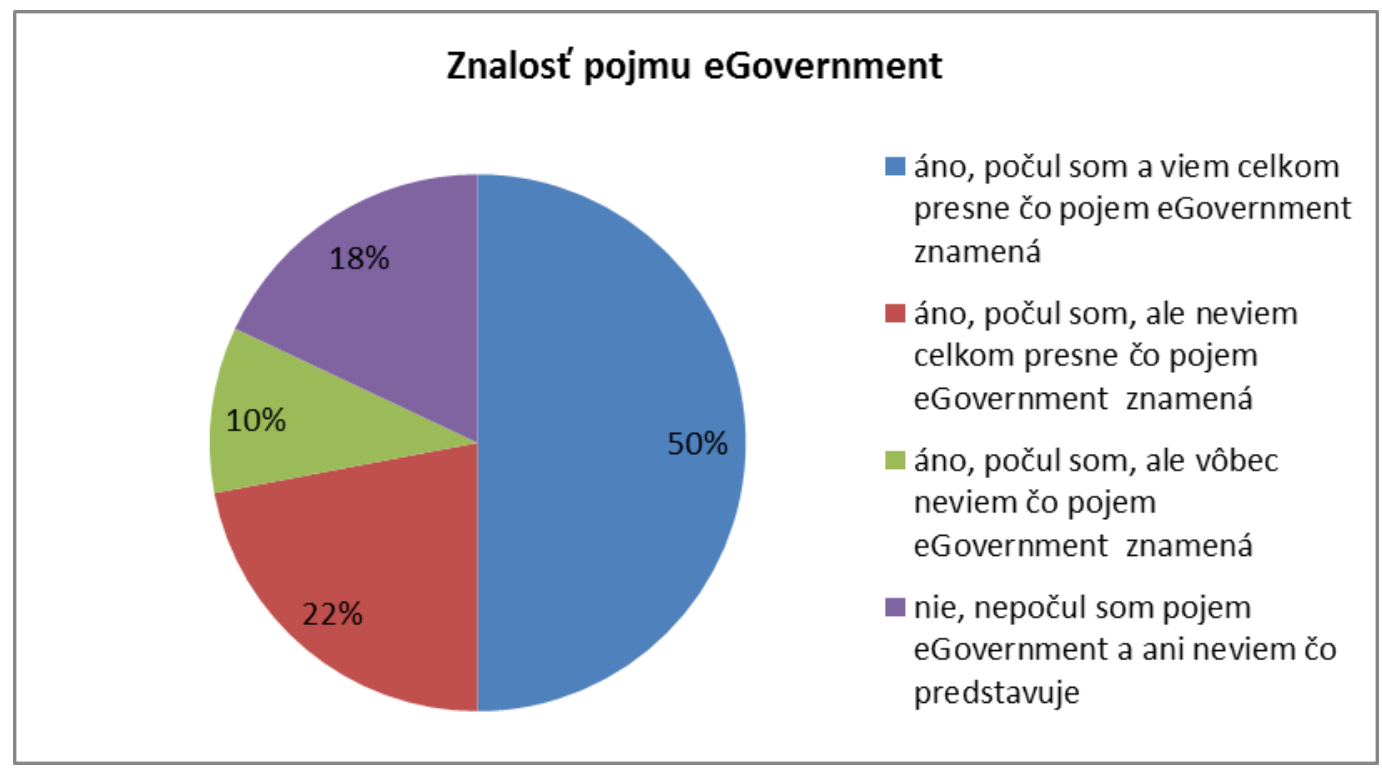

Obrázok 1 Znalost' pojmu eGovernment

Zdroj: Vlastné spracovanie podl'a [9] 
Je možné konštatovat', že $82,2 \%$ respondentov prišlo do kontaktu s týmto pojmom. $\mathrm{Z} 82,2 \%$, čo predstavuje 74 respondentov, $69 \%$ odpovedajúcich boli študenti. $27 \%$ predstavuje pracujúcich, $3 \%$ respondentov bolo $\mathrm{v}$ čase realizácie zberu dát na materskej/rodičovskej dovolenky. Posledné $1 \%$ patrí nezamestnaným.

Otázka : „Akým spôsobom ste sa dozvedeli o eGovernmente?“ priniesla nasledovné zistenia. Otázka bola položená len respondentom, ktorí už pojem eGovernment poznali, základný súbor pre vyhodnotenie tak predstavujú respondenti, ktorí tvoria 82,2 \% $\mathrm{z}$ opýtaných. $\mathrm{Z}$ tohto súboru respondentov sa o eGovernmente dozvedelo $19 \% \mathrm{z}$ médií, 15\% od známych, $15 \% \mathrm{z}$ internetu, $11 \% \mathrm{z}$ odkazu na inej webstránke, $5 \%$ na úrade štátnej správy. Možnost' pridat' vlastný zdroj informácie využilo $19 \%$ respondentov a tí uviedli jednoznačnú odpoved’: „škola“. Zvyšných 16\% neuviedlo žiadnu z možností.

\section{Využivanie služieb eGovernmentu}

„Využívate služby eGovernmentu pri výkone svojho zamestnania, resp. pre osobnú potrebu?“ Zhodnotenie zistených údajov je nasledovné: $10 \%$ z opýtaných využíva elektronické služby verejnej správy pravidelne. $62 \%$ používa služby nepravidelne, alebo aspoň raz už služby využilo. $28 \%$ respondentov nepoužíva služby vôbec. $Z$ toho vyplýva že $72 \%$, opýtaných má niekol'konásobné skúsenosti s využívaním elektronických služieb vlády resp. aspoň raz využili možnost' použit' služby eGovernmentu.

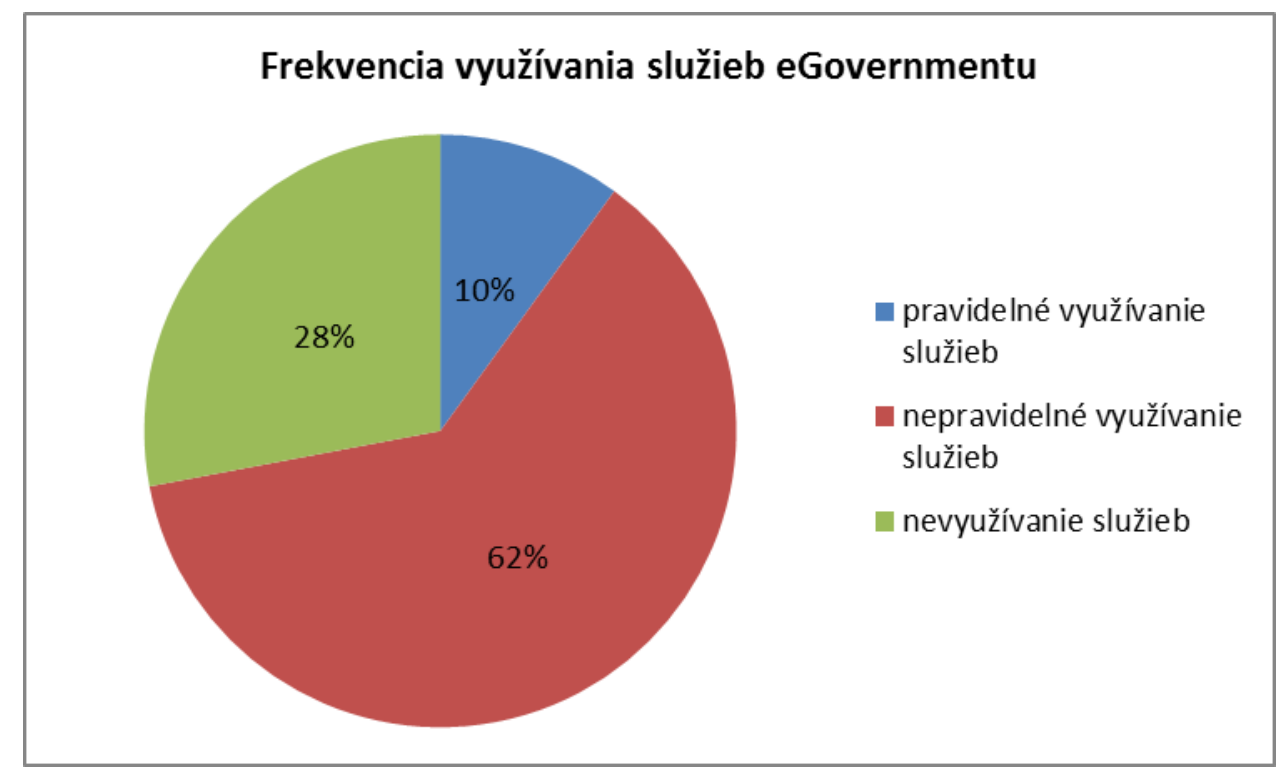

Obrázok 2 Frekvencia využívania služieb e-Governmentu Zdroj: Vlastné spracovanie podla [9]

Používanie špecifických služieb verejnej správy na Slovensku sme sa pokúšali zistit’ otázkou „Akú službu v elektronickej forme využívate z ponuky verejnej správy?“ Poznáme 12 oficiálnych elektronických služieb verejnej správy:

\begin{tabular}{lll}
\hline - Daň z príjmov fyzickej osoby & - Príspevky sociálneho zabezpečenia \\
\hline - Evidencia vozidiel & - Stavebné povolenia \\
- Osobné doklady & - Úradné výpisy z matriky \\
- Oznámenia polícii & • Verejné knižnice \\
- Oznámenia o prest’ahovaní & - Vyhl'adávanie pracovného miesta \\
- Prihlásenie na vysoké školy & - Služby zdravotníctva \\
\hline
\end{tabular}


Najväčší podiel využívanosti dosiahla služba prihlásenie na vysoké školy. Túto možnost' označilo $38 \%$ opýtaných. Predpokladáme, že tento výsledok je prejavom dvoch pragmatických atribútov a to je skutočnost', že ciel'ovým segmentom je kategória študentov vo veku 15 - 25 rokov, pre ktorých je využívanie obdobných služieb bežnou súčast'ou ich každodennej komunikácie a druhým významným atribútom je skutočnost', že celý rad vysokých škôl vyžadoval aj zaslanie elektronickej prihlášky.

Ďalšia otázka týkajúca sa služieb e-Governmentu bola: „Akú formu elektronických služieb verejnej správy využívate?“ Respondenti mali možnost' výberu štyroch foriem využívania služieb eGovernmentu. $Z$ vyhodnotenia je zrejmé, že eGovernment využíva 57\% respondentov prevažne na získavanie informácií. 26\% respondentov komunikuje s verejnou správou obojstranne, posielanie informácií využíva $9 \%$ užívatel'ov a súbory st’ahuje $8 \%$ respondentov.

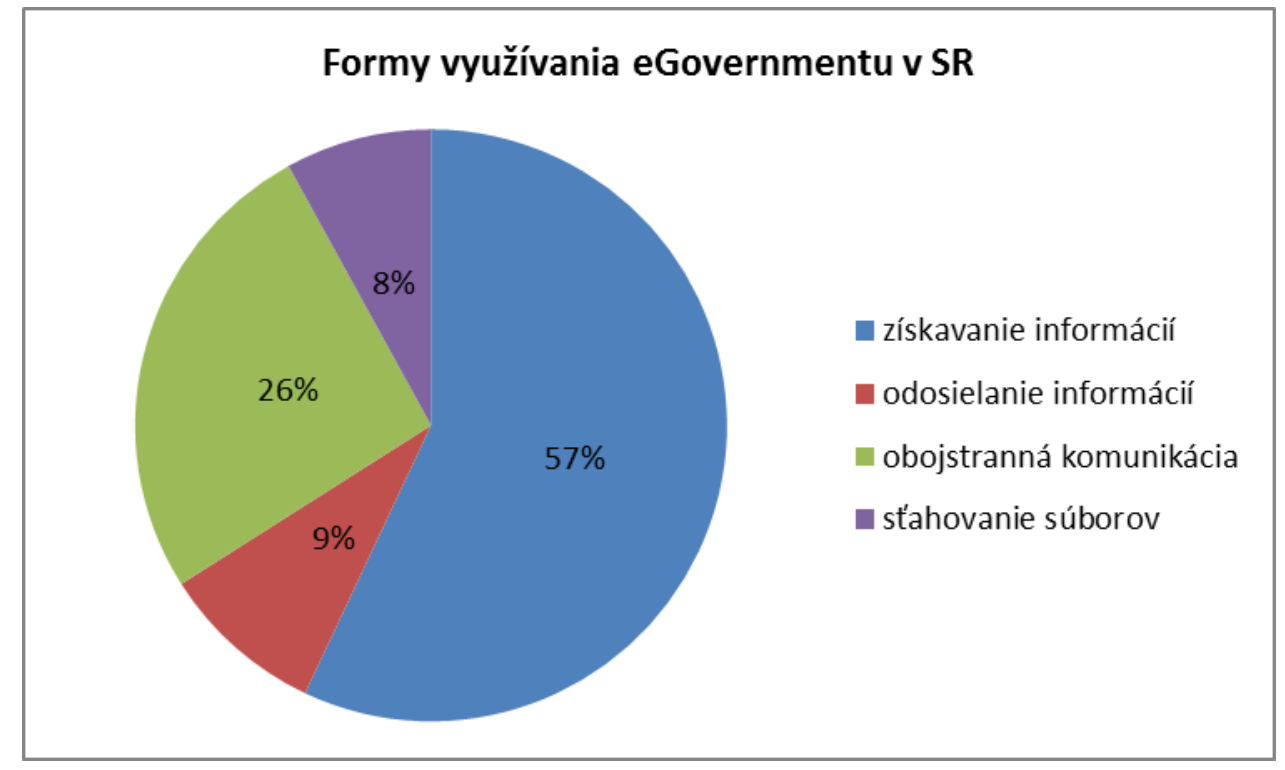

Obrázok 3 Formy využívania e-Governmentu na Slovensku

Zdroj: Vlastné spracovanie podl'a [9]

\section{Očakávania od eGovernmentu}

eGovernment je služba ktorá má priniest' užívatel'om v prvom rade pohodlie a jednoduchost' vybavovania záležitostí voblasti verejnej správy. Tak či tak, názory a preferencie užívatel'ov nemožno odhadovat'. Vo výskume bolo ponúknutých užívatel'om eGovernmentu 9 rôznych atribútov - prínosov, ktoré môžu očakávat' od e-služieb verejnej správy vrátane vyjadrenia neutrálneho stanoviska. Výsledky sa rôznia, avšak stále najočakávanejším prínosom elektronizácie verejnej správy je úspora času, ktorá dostala $83 \%$ odpovedajúcich. Druhý významný prínos služieb je zníženie rozsahu byrokracie so $40 \%$. Jednoduchšie sledovanie transakcií očakáva 38\% respondentov. Úspora peňazí získala 34\%, rovnako ako zrozumitel'nejšie vybavovanie úradných záležitostí. $31 \%$ zo zúčastnených očakáva, že eGovernment im prinesie jednoduchšie sledovanie transakcií. $28 \%$ vidí prínos v skvalitnení služieb verejnej správy, $8 \%$ neočakáva nič, a nakoniec $6 \%$ opýtaných nevie, čo by im mohli elektronické služby verejnej správy priniest'.

Podl'a publikácie Velšica: Občania online sa v obdobnom prieskume na prvom mieste objavuje očakávanie občanov vo forme úspory peňazí. Tento atribút získal $60 \% \mathrm{z}$ celkovej dopytovanej vzorky. Na druhé miesto si l'udia zvolili zjednodušenie vybavovania úradných záležitostí s 33\%, nasledované úsporou financií, ktorú si zvolilo 31\%. Nižšia byrokracia získala $25 \%$ a umiestnila hned' po rýchlejšom vybavovaní úradných záležitostí s $27 \%$. Možnost' priebežne kontrolovat' stav vybavovania, dostupnost' a kvalita informácí pre začatie 
komunikácie, menej administratívnych chýb úradov a úradníkov, žiadne očakávanie, a nevedomost', získali menej ako $15 \%$

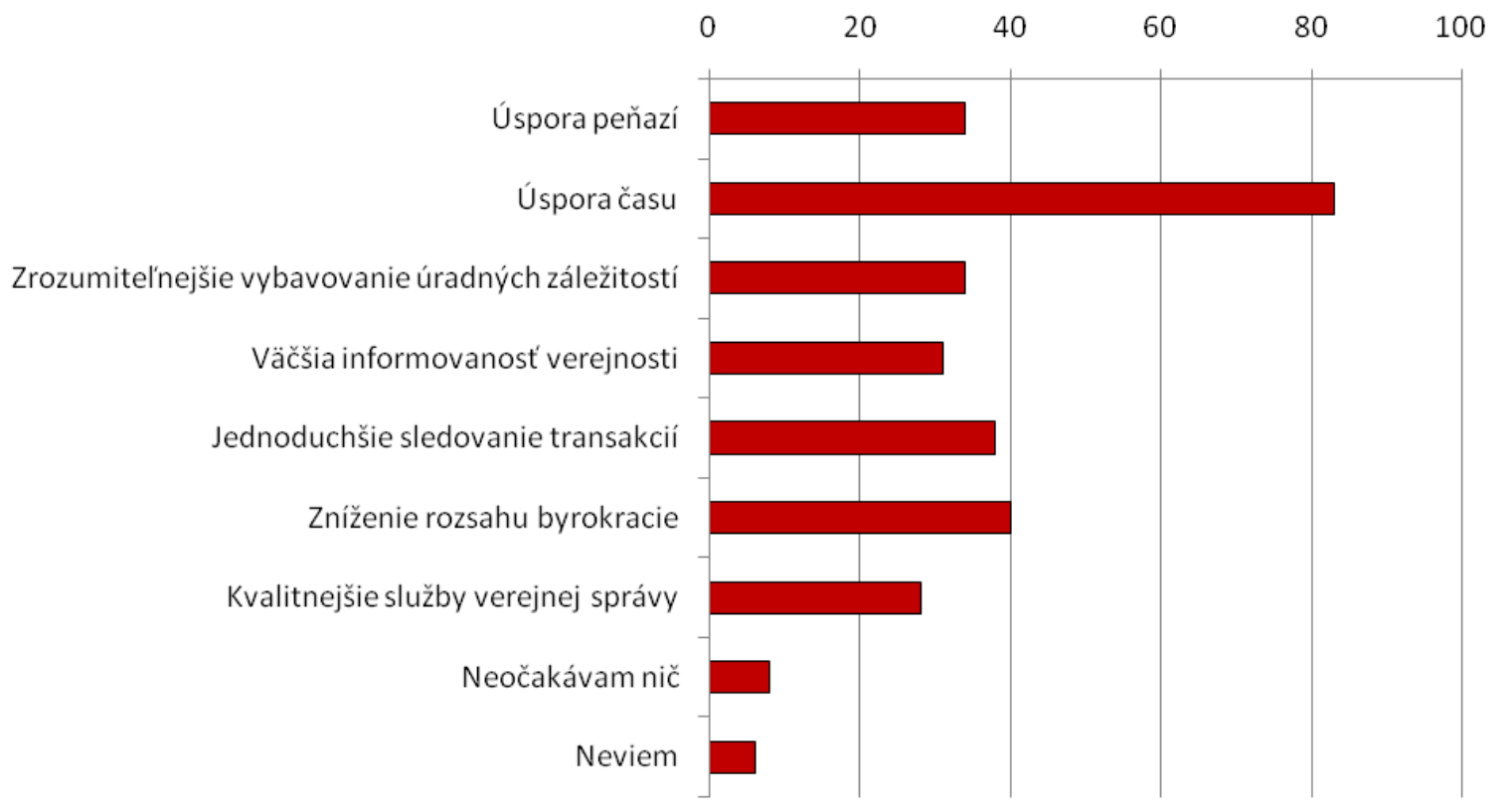

Obrázok 4 Očakávania užívatel'ov e-Governmentu na Slovensku

Zdroj: Vlastné spracovanie podla [9]

Prieskum realizovaný študentmi Katedry spojov len potvrdil, že hlavnou prioritou občanov je úspora času, zrozumitel'nejšie vybavovanie úradných záležitostí a úspora peňazí získalo takmer identické množstvo hlasov ako pri Velšicovom výskume, z čoho môžeme usudzovat', že očakávania používatel'ov eGovernmentu sú aj po piatich rokoch takmer identické a nemenia sa.

\section{Elektronický podpis}

Zákon o elektronickom podpise prijatý v roku 2002 otvoril cestu tejto vymoženosti, a mnohokrát potrebnému nástroju na odosielanie a prijímanie citlivých údajov prostredníctvom siete internet. Elektronický podpis má svoje miesto určené v spekre služieb eGovernmentu, avšak už podl'a skorších výskumov, ho málokto vlastní. Podl'a výročnej správy Ministerstva financií SR v roku 2011, elektronický podpis vlastnilo iba $9 \%$ vzorky. Zaručený elektronický podpis vlastnilo 1\% opýtaných.

Podl'a nášho výskumu, z respondentov ktorí využívajú služby eGovernmentu, 5\% opýtaných vlastní elektronický podpis, $25 \%$ nevlastní, ale rozmýšl'alo o zadovážení elektronického podpisu, $57 \%$ nevlastní elektronický podpis, ale o zakúpení rozmýšllalo, a $14 \%$ respondentov o elektronickom podpise ani nepočulo.

Vzaté z celkového pohl'adu, 95\% opýtaných nevlastní elektronický podpis. V porovnaní z prieskumom Ministerstva Financií, sa nejedná o podstatný rozdiel v náraste užívatel'ov. Avšak v záverečnej správe z roku 2009, je používanie elektronického podpisu respondentmi vnímaná ako jedna štvrtá najväčšia bariéra celkového využívania eGovernmentu. A pokial' l'udia budú brat' elektronický podpis ako bariéru a nie výhodu, prudší nárast vo vývoji využívania samotného elektronického podpisu nemôžeme očakávat'. 


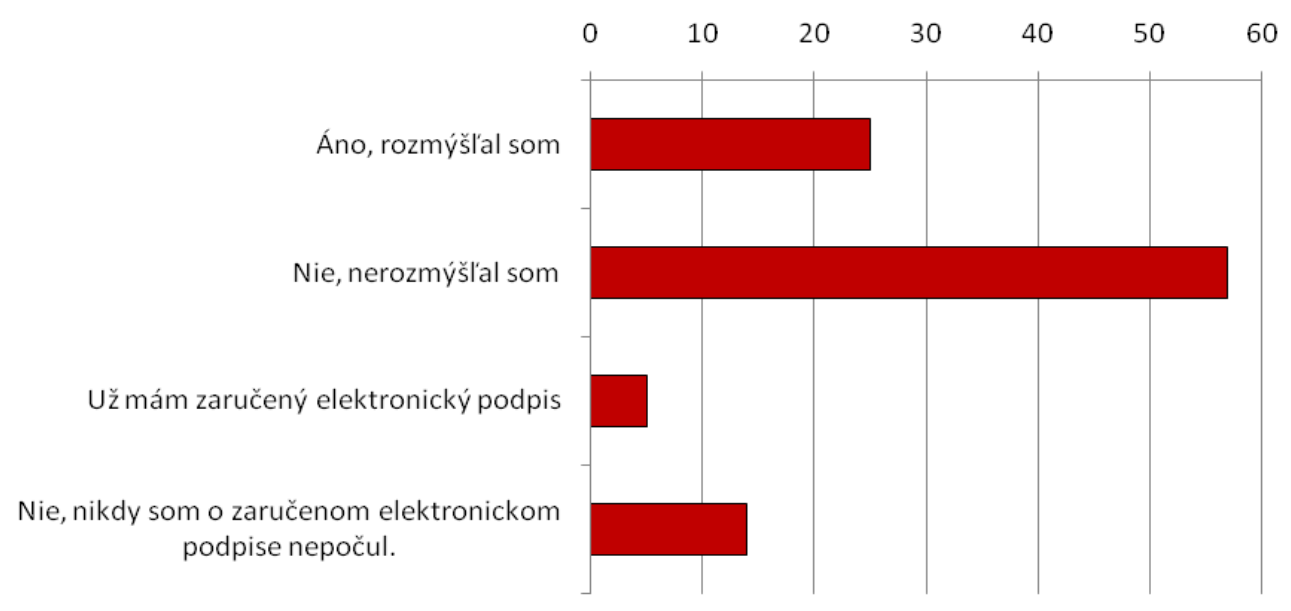

Obrázok 5 Záujem o elektronický podpis na Slovensku

Zdroj: Vlastné spracovanie podl'a [9]

\section{Návšteva stránky portal.gov.sk}

Spoločné prístupové miesto pre zabezpečenie jednotného prístupu k informačným zdrojom a službám verejnej správy v sieti internet portal.gov.sk: Ústredný portál verejnej správy je v prevádzke od roku 2006. Predtým funkciu tohto portálu zabezpečovala stránka občan.sk. Podl'a výskumu z roku 2011, ústredný portál verejnej správy navštívilo 47\% opýtaných, naopak väčšia čast', 53\%, stránku vôbec nenavštívila. Podl'a nami realizovaného výskumu, $11 \%$ respondentov odpovedalo, že stránku navštívilo a navštevuje ju často. $29 \%$ stránku navštívilo, avšak nenavštevujú ju pravidelne. 51\% podl'a výsledkov realizovaného výskumu však stránku nenavštívilo vôbec a $19 \%$ opýtaných o danej stránke ani len nepočulo. Z týchto údajov vyplýva, že $40 \%$ opýtaných využili návštevu stránky portal.gov.sk a $60 \%$ stránku ani raz nenavštívilo. Ako vidno aj v oficiálnom výskume Ministerstva financií SR, väčšina používatel'ov služieb e-governmentu nevyužíva portál vôbec.

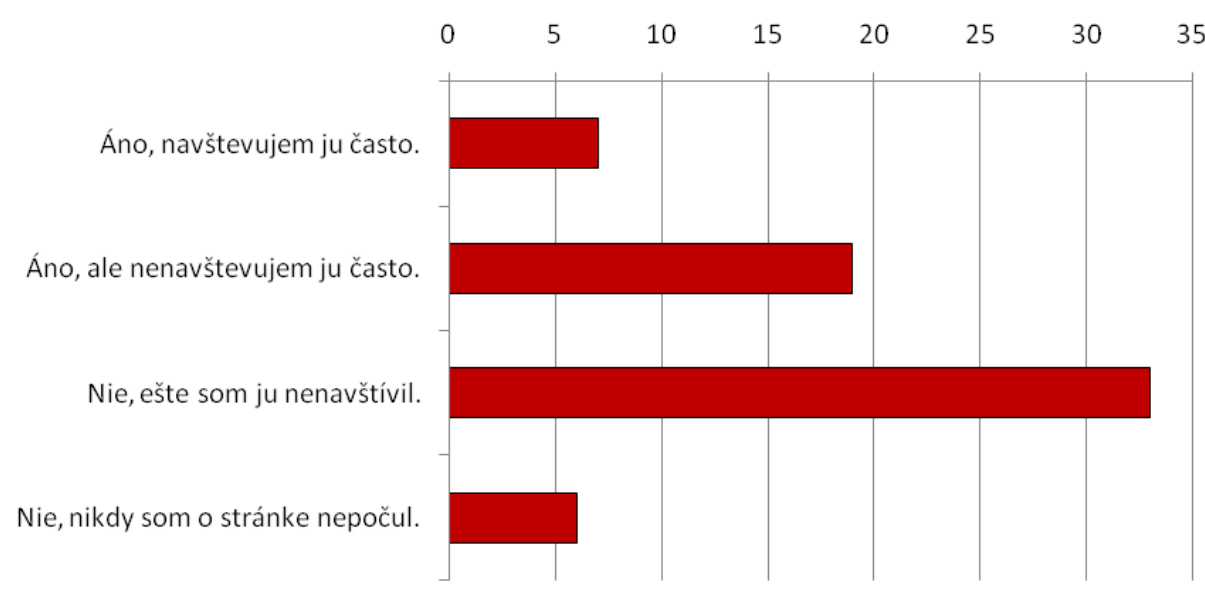

Obrázok 6 Využívanie webového portálu portal.gov.sk

Zdroj: Vlastné spracovanie podla [9]

Z prieskumov realizovaných v roku 2010 vyplýva, že 77\% opýtaných odpovedalo že nepozná webové sídlo portal.gov.sk a len $23 \%$ v tom čase webstránku poznalo.

\section{Dôvera ve-Government}

Posledná výskumná otázka obsahovala vyjadrenie dôvery k systému eGovernment, ktorá je charakterizovaná úrovňou vnímania takých atribútov ako je bezpečnost', 
spol'ahlivost', jednoduchost' a pod. Zo vzorky respondentov, ktorí deklarovali využívanie služieb eGovernmentu vyjadrilo plnú dôveru 32\% respondentov, naopak 3\% vzorky vyjadrilo nedôveru v elektronické verejné služby. $65 \%$ sa nad dôverou v eGovernment nezamýšl'alo. Pozitívne vnímanie dôvery $\mathrm{v}$ eGovernment je potenciálom pre jeho trvalé etablovanie sa a nájdenie nových pravidelných používatel'ov.

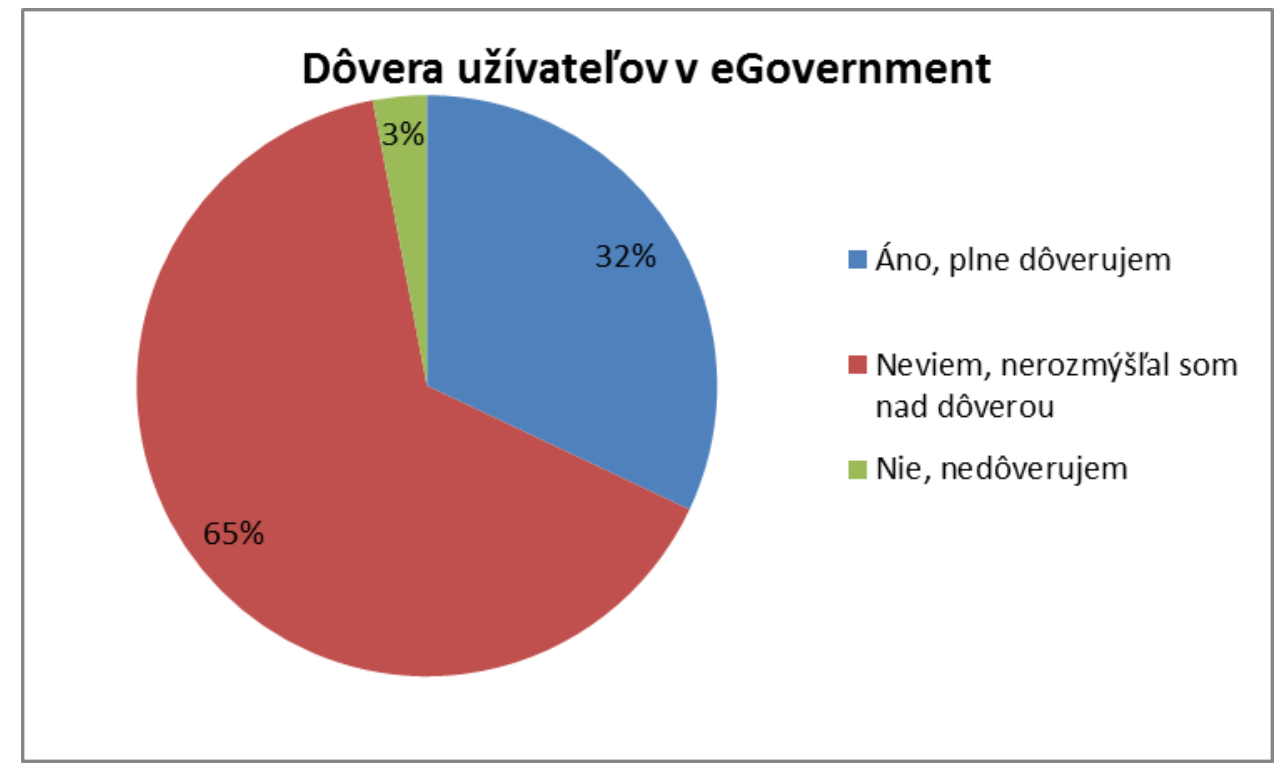

Obrázok 7 Dôvera v eGovernment u užívatel’ov

Zdroj: Vlastné spracovanie podl'a [9]

\section{Zhodnotenie a záver}

Celková úroveň informatizácie vo verejnej správe SR oproti krajinám EÚ stále zaostáva. Svedčí o tom predovšetkým nízka úroveň ponuky elektronických služieb. Z implementácie Cestovnej mapy zavádzania 20 elektronických služieb verejnej správy sa Slovensko nachádza $v$ počiatočnej fáze rozvoja. SR dosahuje približne tretinovú úroveň v porovnaní s priemerom krajín EÚ. V oblasti elektronizácie služieb eGovernmentu, ako napr. eHealth, eWork, eLearning, eCulture, eTourism alebo eInclusion sa rovnako Slovensko stále nemôže vyrovnat' priemeru krajín EÚ.

Napriek mnohým negatívnym aspektom v rozvoji informatizácie verejného sektora za posledné roky, je potrebné podotknút', že podl'a výsledkov štúdie eGovernment Benchmark 2010 pozitívny progres, kde SR v roku 2010 dosiahla pre online dostupnost' 20 základných služieb (v 32 sledovaných krajinách Európy) v priemere 82\%, čo predstavuje nárast o $13 \%$ oproti roku 2009. Popritom celková sofistikovanost' e-služieb v Európe vzrástla za minulý rok o celých $7 \%$ na súčasných $90 \%$. V oboch ukazovatel'och dominuje Rakúsko, Malta, Portugalsko a Írsko, ktoré dosiahli maximálne skóre. Slovenská republika sa oproti ostatnému meraniu zlepšila v dostupnosti e-služieb o $8 \%$ na úroveň $63 \%$. Aj napriek na prvý pohl’ad pozitívnym výsledkom, sa SR nachádza stále hlboko pod európskym priemerom. V súčasnosti SR obsadzuje 28. miesto v oblasti dostupnosti e-služieb.

\section{Literatúra}

[1] Digitizing Public Services in Europe: Putting ambition into action. Capgemini. [online] 2010. [cit. 2012-09-30]. Dostupné na internete: http://www.capgemini.com/insights-and-resources/by-publication/2010-egovernmentbenchmark/ 
[2] E-Government Survey 2010. United Nations. [online] 2010, [cit. 2012-10-14]. Dostupné na internete: http://unpan1.un.org/intradoc/groups/public/documents/undpadm/unpan038853.pdf

[3] MAJERČÁKOVÁ, M. - HOLKA, R.: Nové služby portálu verejnej správ. In: Pošta, Telekomunikácie a Elektronický obchod [elektronický zdroj] : elektronický odborný časopis zameraný na problematiku poštových a telekomunikačných podnikov a oblast' elektronického obchodovania. - ISSN 1336-8281. - 2009. - Roč. 4, č. 2 (2009), s. 46-49.

Spôsob prístupu: http://ks.utc.sk/casopis/pdf/II2009/majercakova_holka.pdf

[4] Metodický pokyn na použitie odborných výrazov pre oblast' informatizácie spoločnosti. Ministerstvo financií SR. [online] 2008, [cit. 2012-10-25]. Dostupné na internete: http://www.informatizacia.sk/terminologia/3480s

[5] Národná koncepcia informatizácie verejnej správy. Úrad vlády SR. [online] 2008, [cit. 2012-09-30]. Dostupné na internete: http://www.informatizacia.sk/narodna-koncepciainformatizacie-verejnej-spravy/1306s

[6] OBI, T.: E-Governance: A Global Perspective on a New Paradigm. IOS Press, 2007. ISBN 978-15-86037-76-5

[7] Operačný program Informatizácia spoločnosti. Úrad vlády SR. [online] 2007, [cit. 2012-10-24] Dostupné na internete: http://www.informatizacia.sk/opis/598s

[8] PRABHU, C. S. R.: E-governance: Concepts And Case Studies. PHI Learning Pvt. Ltd., 2006. ISBN 978-81-20326-47-7.

[9] PRATÁK, R.: eGovernment v Slovenskej republike a perspektívy jeho d'alšieho rozvoja. Bakalárska práca, Katedra spojov, FPEDAS, Žilinská univerzita v Žiline, 2012. (Školitel': L. Madleňáková)

[10] Stratégia informatizácie verejnej správy. Úrad vlády SR. [online] 2008, [cit. 2012-0930]. Dostupné na internete: http://www.informatizacia.sk/strategia-informatizacieverejnej-spravy/1305s

[11] ŠPAČEK, D.: eGovernment - ciele, trendy a př́stupy k jeho hodnocení. Nakladatelství C. H. Beck v Praze, 2012. ISBN 978-80-7400-261-8

[12] The e-government imperative: main findings. In: OECD Policy Brief . Organizácia pre hospodársku spoluprácu a rozvoj. [online] 2003, [cit. 2012-09-26]. Dostupné na internete:

http://www.oecd.org/LongAbstract/0,3425,en_2649_33717_2502533_1_1_1_37421,0 $\underline{0 . h t m l}$

[13] VELŠIC M.: e-Government na Slovensku 2007. Screening elektronických služieb verejnej správy. Bratislava: Inštitút pre verejné otázky, 2007. ISBN 978-80-89345-038

[14] VELŠIC M.: Občania online. Bratislava: Inštitút pre verejné otázky, 2007. ISBN 97880-88935-99-5.

[15] ŽABKOVÁ, D.: Komparácia eGovernmentu v Slovenskej republike a Českej republike. Bakalárska práca, Katedra spojov, FPEDAS, Žilinská univerzita v Žiline, 2012. (Školitel': L. Madleňáková)

[16] http://itapa.sk/egovernment-benchmark-2010/

[17] http://portal.gov.sk/Portal/sk/Default.aspx?CatID=48

[18] http://www.informatizacia.sk/prieskum-spokojnosti-2011/13085s

\section{Grantová podpora}

VEGA 1/0421/12 Modelovanie difúzie znalostí v podnikových hodnotových ret'azcoch 